Technical Note

\title{
Photocatalytic and combined anaerobic-photocatalytic treatment of textile dyes
}

\author{
F. Harrelkas ${ }^{\mathrm{a}, \mathrm{b}}$, A. Paulo ${ }^{\mathrm{c}}$, M.M. Alves ${ }^{\mathrm{c}}$, L. El Khadir ${ }^{\mathrm{b}}$, O. Zahraa ${ }^{\mathrm{d}}$, M.N. Pons ${ }^{\text {a }}$, F.P. van der Zee ${ }^{\mathrm{c}, *}$ \\ ${ }^{a}$ Laboratoire des Sciences du Génie Chimique, CNRS, Nancy University, INPL, 1 Rue Grandville, BP 20451, 54001 Nancy Cedex, France \\ ${ }^{\mathrm{b}}$ Laboratoire d'Automatique et d'Etudes des Procédés, Université Cadi Ayyad, Faculté des Sciences Semlalia, Avenue Prince Mly Abdellah, BP 511, 40000 Marrakech, Morocco \\ ${ }^{\mathrm{c}}$ IBB - Institute for Biotechnology and Bioengineering, Centre of Biological Engineering, University of Minho, Campus de Gualtar, 4710-057 Braga, Portugal \\ ${ }^{\mathrm{d}}$ Département de Chimie-Physique des Réactions, UMR 7630-CNRS, Nancy University, INPL, 1 Rue Grandville, BP 20451, 54001 Nancy Cedex, France
}

\section{A R T I C L E I N F O}

\section{Article history:}

Received 1 February 2008

Received in revised form 13 May 2008

Accepted 16 May 2008

Available online 27 June 2008

\section{Keywords:}

Anthraquinone dyes

Autoxidation

Azo dyes

COD removal

Phthalocyanine dyes

Titanium dioxide

\begin{abstract}
A B S T R A C T
A photocatalytic process based on immobilized titanium dioxide was used to treat crude solutions of azo, anthraquinone and phthalocyanine textile dyes. In addition, the process was applied to the treat autoxidized chemically reduced azo dyes, i.e. representatives of recalcitrant dye residues after biological sequential anaerobic-aerobic treatment. Photocatalysis was able to remove more than $90 \%$ color from crude as well as autoxidized chemically reduced dye solutions. UV-absorbance and COD were also removed but to a lower extent (50\% in average). The end products of photocatalytic treatment were not toxic toward methanogenic bacteria. The results demonstrate that photocatalysis can be used as a pre- or post-treatment method to biological anaerobic treatment of dye-containing textile wastewater. (C) 2008 Elsevier Ltd. All rights reserved.
\end{abstract}

\section{Introduction}

The textile-processing industry is putting a severe burden on the environment, through the release of heavily polluted wastewaters. Biological treatment methods are favored as they are considered environment-friendly and relatively cheap. The most logical biological strategy is sequential anaerobic-aerobic treatment (Field et al., 1995). The anaerobic phase is important for reductive cleavage (decolorization) of azo dyes, as well as for (partial) decolorization of other types of dyes such as anthraquinone, phthalocyanine, and triphenylmethane dyes (Delee et al., 1998). The consecutive aerobic phase would serve to biomineralize aromatic amines from azo dye cleavage (Pinheiro et al., 2004), as well as to remove some of the other types of dyes by adsorption and biodegradation (Easton, 1995). However, there are some limitations: it is not certain that all aromatic amines can be degraded, and the complete removal of other types of dyes is questionable (Van der Zee and Villaverde, 2005). Due to these limitations, more and more research is focusing on combining biological treatment of dye-containing wastewaters with other techniques, such as coagulation-flocculation, adsorption on solids (activated carbon, natural products such as agro wastes), and most importantly advanced oxidation processes (AOPs).

\footnotetext{
* Corresponding author. Tel.: +351253604 400x5413; fax: +351 253678986

E-mail address: frankvdz@deb.uminho.pt (F.P. van der Zee).
}

AOPs are based on the use of the hydroxyl radical as primary oxidant of organic pollutants. These treatments can lead to complete mineralization of organic molecules into $\mathrm{CO}_{2}$ and water (Legrini et al., 1993), with the hetero-atoms being transformed into chloride (Chen et al., 1995), sulfate (Kato et al., 2005), ammonium (Hidaka et al., 1995), etc. Systems such as UV-hydrogen peroxide (Aleboyeh et al., 2005; Baldrian et al., 2006), ozonation (Farré et al., 2005; Liu et al., 2007) and photo-Fenton (Ruppert et al., 1993) have been extensively described in literature and have demonstrated their efficiency. More recently, techniques such as photocatalysis (Ollis, 2000), sonolysis (Drijvers et al., 1999; Minero et al., 2008) and $\gamma$-radiolysis (Getoff, 1996; LaVerne et al., 2007) have shown promising prospects. Solar photocatalysis is especially attractive as it is based on a fully renewable and cheap energy source (Malato et al., 2002). Titanium dioxide is a stable and non-toxic semi-conductor, which is widely used in solar photocatalysis. However, the UV radiation that can be absorbed by $\mathrm{TiO}_{2}$ represents only $5 \%$ of the solar spectrum. This limits the overall yield of the process. In order to improve this yield, combinations with other AOPs have been suggested (Zhang et al., 2008; Neelavannan and Ahmed Basha, 2008). For the treatment of various types of wastewater, including dye-containing textile wastewater, a combination of AOPs with biological processes as pre-treatment and/or polishing step have been suggested (Bousselmi et al., 2002; Bahnemann, 2004). Anaerobic bioprocesses are particularly attractive: their energy input is minimal as no aeration is required. 
In this paper, we report the results of photocatalysis with the use of immobilized $\mathrm{TiO}_{2}$, both as a way to treat crude dyes, and as a post-treatment method for the degradation of autoxidized reduced azo dyes, i.e. representative persistent constituents of biologically treated dye-containing wastewater.

\section{Materials and methods}

\subsection{Dyes}

Solutions of Acid Orange dyes from Sigma-Aldrich and reactive dyes (commercial name: Drimarene) dyes from Clariant (Mutenz, Switzerland) were prepared using de-ionized water. As shown in Table 1, each dye is characterized by its wavelength corresponding to the maximum band of UV-visible absorption $\left(\lambda_{\max }\right)$, as well as by its absorption coefficient $(\varepsilon)$. Reactive dyes were hydrolyzed prior to use by heating the solutions at $80^{\circ} \mathrm{C}$ for $1 \mathrm{~h}$ after adjusting the $\mathrm{pH}$ to 10 using $2 \mathrm{~N} \mathrm{NaOH}$.

\section{Photocatalysis experiments}

The photocatalytic reactor (Fig. 1) consisted of a $37^{\circ}$ slanted aluminium plate with a working area of $30 \times 30 \mathrm{~cm}^{2}$ (Alinsafi et al., 2007). The aluminium surface was inactivated by coating it with a thin layer of PTFE (PTFE AL, Samaro, Villeurbanne, France). The solution to be treated flowed as a thin film from the top of the chamber over a non-woven fabric made of cellulose fibers on which Tiona PC500 $\mathrm{TiO}_{2}\left(18 \mathrm{~g} \mathrm{~m}^{-2}\right)$, UOP 2000 zeolite $\left(2 \mathrm{~g} \mathrm{~m}^{-2}\right)$ and Snowtex $50 \mathrm{SiO}_{2}\left(20 \mathrm{~g} \mathrm{~m}^{-2}\right)$ have been fixed by compression (gift from Ahlstrom, Pont-Evêque, France). A transparent glass sheet covered the reacting chamber to avoid evaporation of the solution. The sample to be treated was stored in a reservoir (vol-

Table 1

Characteristics of dyes

\begin{tabular}{|c|c|c|c|c|}
\hline Name & Type $^{\mathrm{a}}$ & Structure & $\lambda_{\max }(\mathrm{nm})$ & $\varepsilon\left(\lg ^{-1} \mathrm{~cm}^{-1}\right)$ \\
\hline Acid Orange 10 & azo & Hо & 480 & 42.9 \\
\hline Acid Orange 12 & azo & & 486 & 48.2 \\
\hline Reactive Black 5 & azo & & 595 & 22.7 \\
\hline Reactive Orange KGL & azo & Structure unknown ${ }^{\mathrm{b}}$ chromophore: $\mathrm{R}_{1}-\mathrm{N}=\mathrm{N}-\mathrm{R}_{2}\left(\mathrm{R}_{1}\right.$ and $\mathrm{R}_{2}$ are aromatic ring structures $)$ & 398 & 16.5 \\
\hline Reactive Violet K2LR & azo & Structure unknown ${ }^{\mathrm{b}}$ chromophore: $\mathrm{R}_{1}-\mathrm{N}=\mathrm{N}-\mathrm{R}_{2}\left(\mathrm{R}_{1}\right.$ and $\mathrm{R}_{2}$ are aromatic ring structures) & 549 & 12.5 \\
\hline Reactive Blue K2LR & azo (form) & $\mathrm{R}_{2} \mathrm{~N}-\mathrm{R}_{3}\left(\mathrm{R}_{1}-\mathrm{R}_{3}\right.$ are aromatic ring & 614 & 16.0 \\
\hline Reactive Blue KBL & anth & Structure unknown ${ }^{\mathrm{b}}$ chromophore: & 591 & 10.8 \\
\hline Reactive Green K5BL & phth & Structure unknown ${ }^{\mathrm{b}}$ chromophore: & 658 & 24.1 \\
\hline
\end{tabular}

a Dye type: azo = azo dye, form = formazan dye, anth = anthraquinone dye, phth = phthalocyanine dye; all reactive dyes were hydrolyzed prior to use.

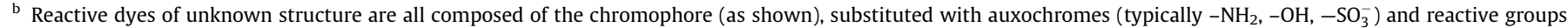
(typically triazinyl or vinyl sulfonyl). 
front view

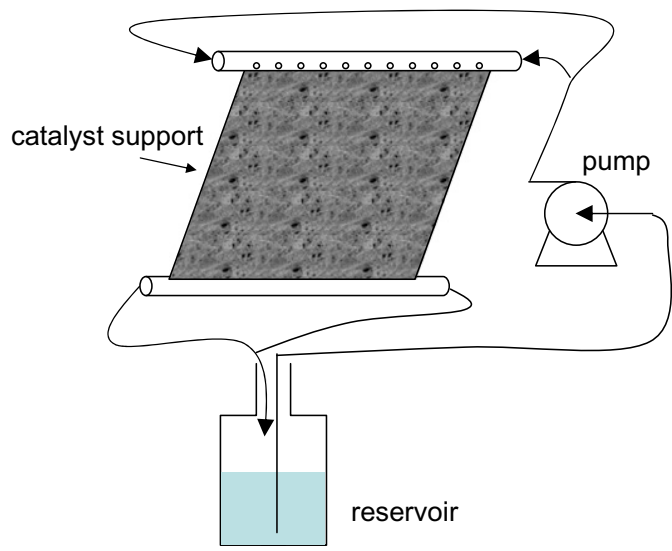

side view

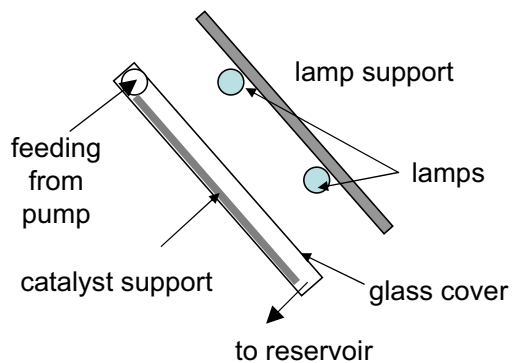

Fig. 1. Schematic presentation of the photocatalytic reactor.

Table 2

Chemical and biological dye decolorization and autoxidation of reduced dye solutions upon exposure to oxygen

\begin{tabular}{|c|c|c|c|c|c|c|c|c|c|}
\hline \multicolumn{2}{|l|}{ Compound } & \multicolumn{3}{|c|}{ Chemical/biological decolorization $^{\mathrm{a}}$} & \multicolumn{5}{|c|}{ Autoxidation } \\
\hline \multirow[t]{2}{*}{ Name } & \multirow[t]{2}{*}{$\overline{\text { Type }^{\mathrm{b}}}$} & \multicolumn{2}{|c|}{ Color removal at $\lambda_{\max }{ }^{c}$} & \multirow[t]{2}{*}{ Residual color } & \multirow[t]{2}{*}{$\mathrm{y} / \mathrm{n}$} & \multirow[t]{2}{*}{ Color } & \multirow[t]{2}{*}{$\%$ Abs at orig. $\lambda_{\max }(\%)$} & \multirow[t]{2}{*}{ New $\lambda_{\max }(\mathrm{nm})$} & \multirow[t]{2}{*}{$\varepsilon\left(\lg ^{-1} \mathrm{~cm}^{-1}\right)$} \\
\hline & & \%Chem. & \%Biol. & & & & & & \\
\hline Acid Orange 10 & azo & 91 & n.a. & Greenish yellow & $\mathrm{y}$ & Dark red & 9 & $-{ }^{d}$ & $-{ }^{\mathrm{d}}$ \\
\hline Acid Orange 12 & azo & 87 & n.a. & Slightly yellowish & $\mathrm{y}$ & Dark brown & 13 & 462 & 6.3 \\
\hline Reactive Black 5 & azo & $(79)^{\mathrm{e}}$ & $(85)^{\mathrm{e}}$ & Slightly brownish & $\mathrm{y}$ & Blue & 20 & 602 & 4.5 \\
\hline Reactive Orange KGL & azo & 96 & 92 & & $\mathrm{y}$ & Violet & 5 & 540 & 1.6 \\
\hline Reactive Violet K2LR & azo & 99 & 91 & & $\mathrm{y}$ & & 5 & $-^{c}$ & 3.2 \\
\hline Reactive Blue K2LR & form & $96^{\mathrm{f}}$ & 100 & & $\mathrm{y}$ & & 3 & $-^{c}$ & 2.1 \\
\hline Reactive Blue KBL & anth & $94^{\mathrm{f}}$ & 7 & Bright yellow & $\mathrm{n}$ & & - & - & - \\
\hline Reactive Green K5BL & phth & $35^{\mathrm{f}}$ & 0 & & $\mathrm{n}$ & & - & - & - \\
\hline
\end{tabular}

a Chemical decolorization by $\mathrm{H}_{2}$ using Pd as catalyst; Biological decolorization in anaerobic bioassays using vfa-fed anaerobic granular sludge.

b Dye type: $a z o=$ azo dye, form = formazan dye, anth = anthraquinone dye, phth = phthalocyanine dye; all reactive dyes were hydrolyzed prior to further treatment

c Listed data represent average values of duplicates/triplicates, data range less $\pm 5 \%$.

d No peak, low absorbance over entire UV-vis area.

e Real values are higher since autoxidation could not be prevented. Visual observation indicates near to complete color removal.

${ }^{f}$ Slow reaction: value represents chemical color removal of a diluted dye solution $\left(50 \mathrm{mg} \mathrm{l}^{-1}\right)$.

ume given in Table 2) and was continuously circulated in the system by a peristaltic pump at a constant flow rate of $200 \mathrm{ml} \mathrm{min}^{-1}$, thereby permitting optimal distribution of the liquid over the catalytic support. PTFE tubing was used. The reservoir was open to air to ensure sufficient oxygenation. Artificial irradiation was provided by two UV lamps emitting light with a wavelength around $365 \mathrm{~nm}$ (F15T8, BLB 15W, Duke, Essen, Germany). The lights were positioned in parallel to the reactor. Light was turned on at the beginning of each experiment. After each experimental run, the photoreactor was rinsed with de-ionized water under UV irradiation.

\section{Anaerobic biological dye reduction}

Anaerobic biological reduction was performed in $160 \mathrm{ml}$ glass bottles sealed with butyl rubber stoppers, containing $50 \mathrm{ml}$ of a nutrient medium with (in $\mathrm{mg} \mathrm{l}^{-1}$ ): $\mathrm{NH}_{4} \mathrm{Cl}$ (160), $\mathrm{CaCl}_{2}$ (10), $\mathrm{KH}_{2} \mathrm{PO}_{4} \cdot 3 \mathrm{H}_{2} \mathrm{O}$ (328), $\mathrm{MgSO}_{4} \cdot 6 \mathrm{H}_{2} \mathrm{O}(100), \mathrm{FeCl}_{2} \cdot 4 \mathrm{H}_{2} \mathrm{O}(2), \mathrm{H}_{3} \mathrm{BO}_{3}$ (0.05), $\mathrm{ZnCl}_{2}$ (0.05), $\mathrm{CuCl}_{2} \cdot 2 \mathrm{H}_{2} \mathrm{O}$ (0.038), $\mathrm{MnCl}_{2} \cdot 2 \mathrm{H}_{2} \mathrm{O}$ (0.41), $\left(\mathrm{NH}_{4}\right)_{6} \mathrm{Mo}_{7} \mathrm{O}_{24} \cdot 4 \mathrm{H}_{2} \mathrm{O}$ (0.05), $\mathrm{AlCl}_{3}$ (0.049), $\mathrm{CoCl}_{2} \cdot 6 \mathrm{H}_{2} \mathrm{O}$ (2), $\mathrm{NiCl}_{2} \cdot 6 \mathrm{H}_{2} \mathrm{O}(0.092), \mathrm{NaSeO}_{3} \cdot 5 \mathrm{H}_{2} \mathrm{O}(0.164)$. The headspace was filled with a mixture of $\mathrm{N}_{2}$ and $\mathrm{CO}_{2}$ (ratio $80 \% / 20 \%$ ). The substrate was composed of a $\mathrm{NaOH}$-neutralized mixture of volatile fatty acids (acetate, propionate and butyrate at a 1:1:1 COD-based ratio) representing a total COD concentration of $2 \mathrm{~g} \mathrm{l}^{-1}$. The medium was buffered at a pH $7.3 \pm 0.2$ by addition of $\mathrm{NaHCO}_{3}\left(5 \mathrm{~g} \mathrm{l}^{-1}\right)$. Nonacclimated anaerobic granular sludge from a brewery wastewater treatment plant was added to a concentration of $0.8 \mathrm{~g} \mathrm{VSS} 1^{-1}$. After pre-incubation for $24 \mathrm{~h}$ at $30^{\circ} \mathrm{C}$, dyes were added to a final concentration of $200 \mathrm{mg} \mathrm{l}^{-1}$ with a syringe from $5 \mathrm{~g} \mathrm{l}^{-1}$ stock solutions.

\section{Chemical dye reduction}

Chemical dye reduction was achieved by bubbling hydrogen at low flow through $70 \mathrm{ml}$ glass bottles containing $50 \mathrm{ml}$ of concentrated dye solutions $\left(5 \mathrm{~g} \mathrm{l}^{-1}\right)$ and $100 \mathrm{mg}$ of the hydrogenation catalyst $10 \%$ palladium on barium sulfate (Sigma-Aldrich). The reaction was allowed to continue during the night $(\sim 14 \mathrm{~h})$, which was mostly sufficient to decolorize concentrated dye solutions. In case no substantial decolorization had taken place, it was verified whether any reductive decolorization reaction could be achieved, by repeating the procedure using a much more diluted dye solution $\left(50 \mathrm{mg} \mathrm{l}^{-1}\right)$.

\section{Analytical procedures}

The reactions were monitored by UV-visible spectrophotometry using a SECOMAM (Domont, France) Anthelie Light device in the range $200-800 \mathrm{~nm}$ for experiments run in France and a JASCO 
V-560 device for experiments run in Portugal. COD was measured on a Hach 2400 (Loveland, Colorado, USA) (Method 8000). BOD was determined by using the manometric Oxitop ${ }^{\circledR}$ method (WTW Measurement Systems, Weilheim, Germany). The $\mathrm{pH}$ and the conductivity were measured by using, respectively, a PHM 220 pHmeter and a CDM 210 conductimeter (Radiometer Analytical SAS, Villeurbanne, France).

For the spectrometric assessment of chemically or biologically reduced, samples were diluted in a phosphate buffer $\left(10.86 \mathrm{~g} \mathrm{l}^{-1}\right.$ $\left.\mathrm{NaHPO}_{4} \cdot 2 \mathrm{H}_{2} \mathrm{O}, 5.38 \mathrm{~g} \mathrm{l}^{-1} \mathrm{Na}_{2} \mathrm{HPO}_{4} \cdot \mathrm{H}_{2} \mathrm{O}\right)$ containing $200 \mathrm{mg} \mathrm{l}^{-1}$ ascorbic acid, respectively to avoid color shifts due to $\mathrm{pH}$ changes and to prevent autoxidation of aromatic amines.

Methane production was monitored by gas chromatography (Chrompack Haysep Q column on a Chrompack 9001 gas chromatograph). The methane concentration was expressed in terms of $\mathrm{CH}_{4}$-COD.

\section{Results and discussion}

The color removal percentages listed in Table 2 for chemical reduction with hydrogen show that all dyes were at least partly decolorized. All of the azo dyes tested were near-completely decolorized by overnight bubbling with $\mathrm{H}_{2}$ with $\mathrm{Pd}$ as catalyst was mostly sufficient to achieve this reduction in concentrated $\left(5 \mathrm{gl}^{-1}\right)$ azo dye solutions. In azo dyes, the azo bond is cleaved yielding colorless amines (Stolz, 2001; Pearce et al., 2003), which explains the decolorization of the solution. Also two of the nonazo dyes, the formazan dye Reactive Blue K2LR and the anthraquinone dye Reactive Blue KBL could be decolorized chemically, albeit slower than the azo dyes. Concentrated solutions $\left(5 \mathrm{~g} \mathrm{l}^{-1}\right)$ of these dyes were only decolorized for $20-25 \%$ during overnight bubbling with $\mathrm{H}_{2}$. However, near-complete decolorization was achieved with diluted solutions $\left(50 \mathrm{mg} \mathrm{l}^{-1}\right.$ ), which indicates the property of these dyes to be reductively decolorized. In contrast to azo, formazan and anthraquinone dyes, the phthalocyanine dye Reactive
Green K5BL was hardly decolorized and the same applied for another phthalocyanine dye tested (Reactive Green K4GN, data not shown). It was found that even in diluted dye solutions (50 $\mathrm{mg} \mathrm{l}^{-1}$ ), the color removal was not more than $35 \%$, possibly a result of adsorption rather than reductive transformation.

In order to verify whether chemical dye reduction is suitable to mimic, in a fast way, the fate of dyes in anaerobic biological treatment systems, a series of dye-amended batch vials was incubated with anaerobic granular sludge and the decolorization was followed in time. Table 2 lists the color removal efficiencies obtained after 12-16 days of incubation. It is seen that biological decolorization of azo and formazan dyes is very similar to chemical azo dye reduction. Less similar, but still rather alike, are the results with the phthalocyanine dye, i.e. poor chemical vs. no biological decolorization. In fact, reversible decolorization is common for this type of dyes (Nigam et al., 1996; Lee et al., 2006). In contrast, the anthraquinone dye could be decolorized by hydrogen but was hardly affected by anaerobic biological treatment. This apparent anaerobic stability is not typical for anthraquinone dyes, as it has been demonstrated that most anthraquinone dyes studied are at least partly biologically decolorized under anaerobic conditions (Dos Santos et al., 2005; Lee et al., 2006). All reduced azo dye solutions were observed to autoxidize upon exposure to oxygen, yielding colored compounds with a $\lambda_{\max }$ distinct from that of the original dye. Especially aromatic amines with ortho-substituted hydroxyl groups, which include a large fraction of the constituent aromatic amines from azo dyes, are susceptible to autoxidation. The reaction may be a relatively small change of the molecule but it may also involve aromatic ring opening or dimerization (Kudlich et al., 1999). Autoxidation reactions are fast and irreversible and cannot be avoided when anaerobic reduction is followed by either aerobic biological treatment or by photocatalytic polishing, which requires oxygen for the production of hydroxyl and hydroperoxyl radicals.

Table 3 summarizes the results of photocatalytic treatment applied to dye solutions and to autoxidized (chemically) reduced dye

Table 3

Removal of color, UV and COD during photochemical treatment of dye solutions and autoxidized (chemically) reduced dye solutions

\begin{tabular}{|c|c|c|c|c|c|c|c|c|c|c|c|c|c|c|}
\hline \multicolumn{2}{|l|}{ Compound } & \multicolumn{2}{|c|}{ Initial amount of dye } & \multicolumn{4}{|c|}{ Color removal } & \multicolumn{4}{|c|}{ UV-removal } & \multicolumn{3}{|c|}{ COD-removal } \\
\hline Name $^{\mathrm{a}}$ & Type $^{\text {b }}$ & $\begin{array}{l}\text { Initial conc. } \\
\left(\mathrm{mg} \mathrm{l}^{-1}\right)\end{array}$ & $\begin{array}{l}\text { Volume } \\
(\mathrm{ml})\end{array}$ & $\begin{array}{l}\lambda_{\max } \\
(\mathrm{nm})\end{array}$ & $\begin{array}{l}t=2 \mathrm{~h} \\
(\%)\end{array}$ & $\rightarrow$ & $\begin{array}{l}t=t_{\text {end }} \% \\
\left(t_{\text {end }} ; \mathrm{h}\right)\end{array}$ & $\begin{array}{l}\lambda \\
(\mathrm{nm})\end{array}$ & $\begin{array}{l}t=2 \mathrm{~h} \\
(\%)\end{array}$ & $\rightarrow$ & $\begin{array}{l}t=t_{\text {end }} \% \\
\left(t_{\text {end }} ; \mathrm{h}\right)\end{array}$ & $\begin{array}{l}t=2 \mathrm{~h} \\
(\%)\end{array}$ & $\rightarrow$ & $\begin{array}{l}t=t_{\text {end }} \% \\
\left(t_{\text {end }} ; \mathrm{h}\right)\end{array}$ \\
\hline Acid Orange 10 & azo & 50 & 180 & 480 & 92 & $\rightarrow$ & $92(3.0)$ & 248 & 50 & $\rightarrow$ & $58(3.0)$ & n.a. ${ }^{\mathrm{c}}$ & $\rightarrow$ & n.a. ${ }^{c}$ \\
\hline Acid Orange 10 & azo & 61 & 550 & 480 & & & $100(29.3)$ & 248 & & & $96(29.3)$ & & $\rightarrow$ & $72(29.3)$ \\
\hline $\begin{array}{l}\text { Autox. red. Acid Orange } \\
10\end{array}$ & aa & $50^{d}$ & 180 & $-^{e}$ & & & & 235 & 59 & $\rightarrow$ & $72(3.0)$ & 59 & $\rightarrow$ & $65(3.0)$ \\
\hline $\begin{array}{l}\text { Autox. red. Acid Orange } \\
\qquad 10\end{array}$ & aa & $61^{d}$ & 550 & $-e^{e}$ & & & & 235 & & & $90(30.4)$ & & $\rightarrow$ & $70(30.4)$ \\
\hline Acid Orange 12 & azo & 50 & 180 & 486 & 93 & $\rightarrow$ & $99(5.1)$ & 240 & 67 & $\rightarrow$ & $89(5.1)$ & 49 & $\rightarrow$ & $68(5.1)$ \\
\hline $\begin{array}{l}\text { autox. red. Acid Orange } \\
\quad 12\end{array}$ & aa & $50^{d}$ & 180 & 450 & 75 & $\rightarrow$ & $96(6.6)$ & 227 & 25 & $\rightarrow$ & $61(6.6)$ & 19 & $\rightarrow$ & $50(6.6)$ \\
\hline Reactive Black 5 & azo & 99 & 180 & 595 & 97 & $\rightarrow$ & $100(5.1)$ & 230 & 21 & $\rightarrow$ & $59(5.1)$ & 28 & $\rightarrow$ & $28(5.1)$ \\
\hline $\begin{array}{l}\text { autox. red. Reactive } \\
\text { Black } 5\end{array}$ & aa & $99^{d}$ & 180 & 593 & 83 & $\rightarrow$ & $100(4.5)$ & 260 & 75 & $\rightarrow$ & $90(4.5)$ & 69 & $\rightarrow$ & $70(4.5)$ \\
\hline Reactive Orange KGL & azo & 50 & 500 & 389 & 96 & & & 225 & 52 & & & 48 & & \\
\hline $\begin{array}{l}\text { autox. red. Reactive } \\
\text { Orange KGL }\end{array}$ & aа & $50^{d}$ & 500 & 389 & 48 & & & 225 & 74 & & & 64 & & \\
\hline Reactive Violet K2LR & azo & 50 & 500 & 549 & 95 & & & 219 & 72 & & & 53 & & \\
\hline $\begin{array}{l}\text { autox. red. Reactive } \\
\text { Violet K2LR }\end{array}$ & aа & $50^{d}$ & 500 & $-^{e}$ & & & & 219 & 84 & & & 62 & & \\
\hline Reactive Blue K2LR & form & 50 & 500 & 614 & 97 & & & 278 & 85 & & & 62 & & \\
\hline Reactive Blue KBL & anth & 50 & 500 & 591 & 99 & & & 278 & 85 & & & 52 & & \\
\hline Reactive Green K5BL & phth & 50 & 500 & 658 & 98 & & & 224 & 83 & & & 68 & & \\
\hline
\end{tabular}

a 'autox. red.' stands for autoxidized chemically reduced.

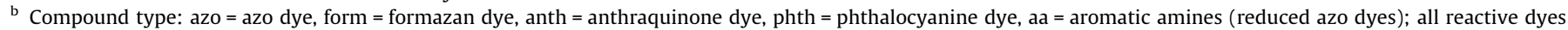
were hydrolyzed prior to use.

c n.a. = Not available (COD measurements failed).

d Dye concentration from which the reduced dye originates.

e Reduced compound has only a faint color and there is no absorbance peak in the visual area. 

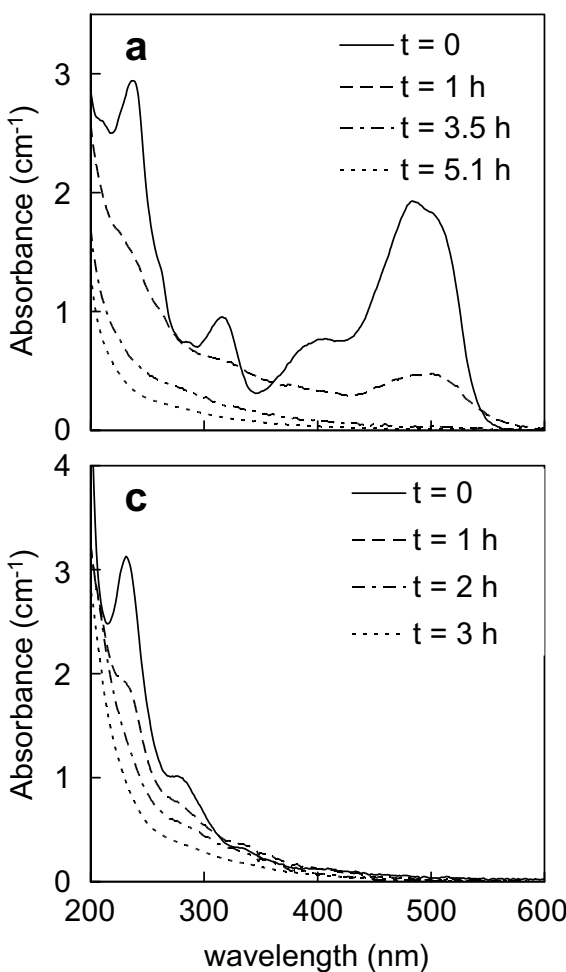

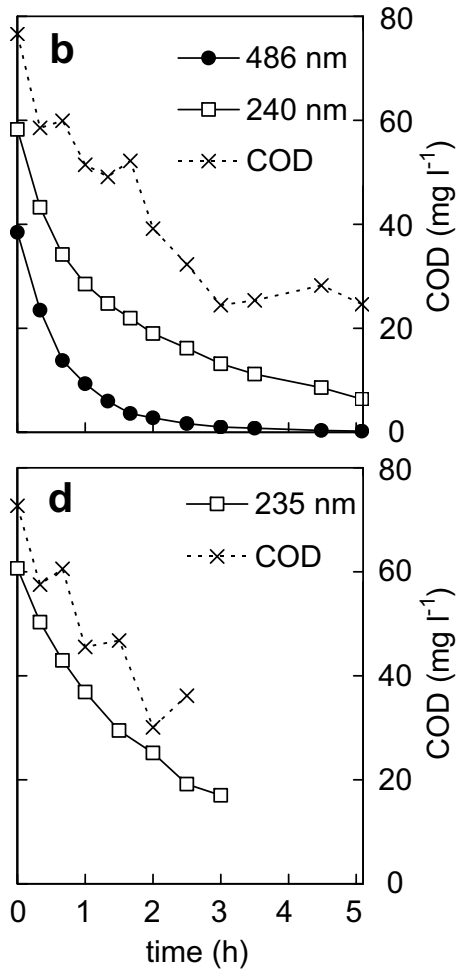

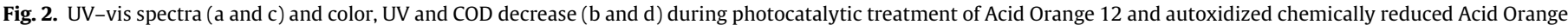
10 , respectively.

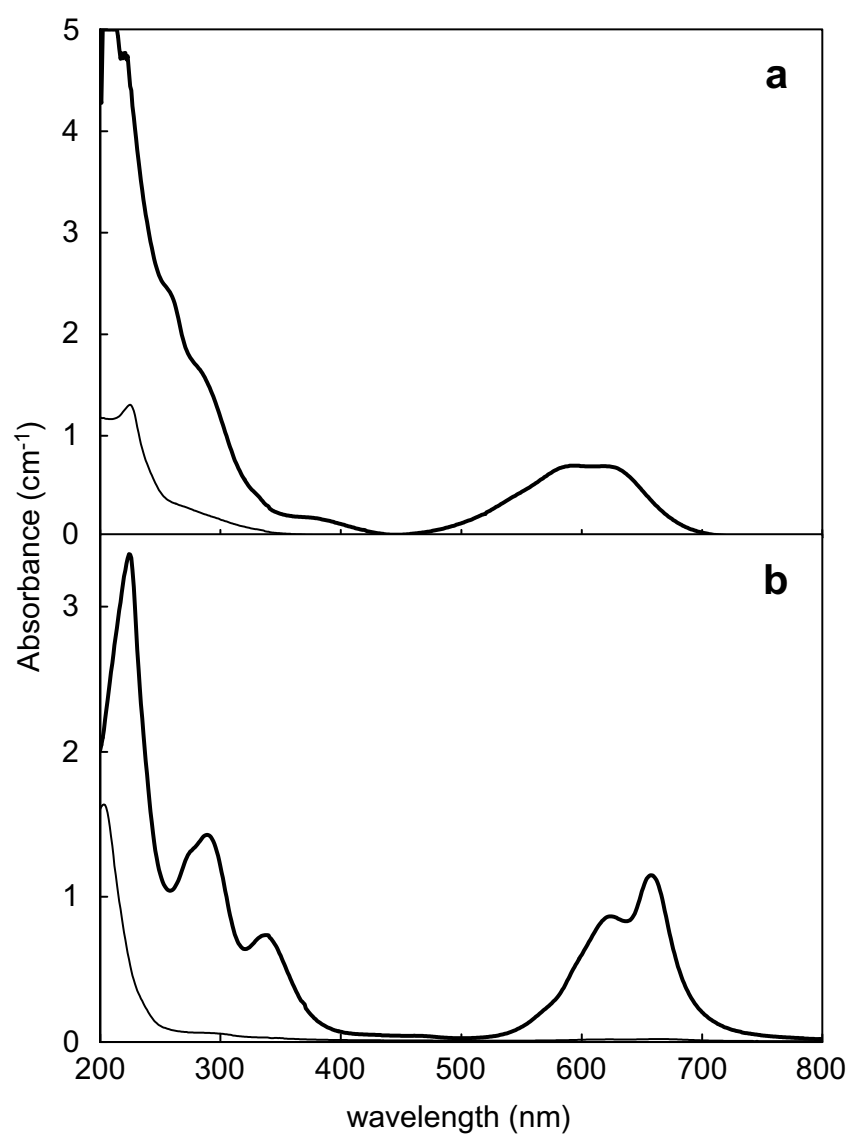

Fig. 3. UV-visible spectra of Reactive Blue KBL (a) and Reactive Green K5BL (b) before (thick line) and after (thin line) photocatalysis. solutions. Examples are shown in Figs. 2 and 3. For each compound, either the original dye or the autoxidized reduced dye, a wavelength in the UV range was chosen corresponding to a peak or a shoulder in the spectrum at $t=0$. Photocatalytic treatment led to removal of color, UV-absorbance and COD with all of the compounds tested. Color removal was always higher than UV-absorbance removal. UV-absorbance is generally associated with aromatic rings, which are more difficult to open (Theurich et al., 1997; Prevot et al., 2001). Color removal is much faster than COD removal, the color removal being generally close to its end value after $2 \mathrm{~h}$, which is not the case for COD removal. The COD removal observed for Reactive Black 5 is much lower than the value given by Arslan and Balcioğlu (1999) but an exact comparison is difficult as the reactor setup and the type of $\mathrm{TiO}_{2}$ were different.

The relatively low color removal observed with autoxidized reduced azo dyes reflects the low initial color of these samples. Even if the color is removed, there is usually some UV-absorbance left. In general, the removal of UV-absorbance and COD was higher with autoxidized reduced azo dyes than with untreated azo dyes. This trend was most obvious with Reactive Black 5 vs. its autoxidized reduced analogue. However, the opposite trend was observed with Acid Orange 12 vs. its autoxidized reduced analogue. The apparent recalcitrance of autoxidized reduced Acid Orange 12 to photocatalytic oxidation may be related to the fact that its naphthalenebased amine (i.e. the structure prone to autoxidation) has less substituents than the naphthalene-based amines from the other azo dyes tested. However, as autoxidation reactions are complex (Kudlich et al., 1999), it is not possible to predict whether this observation represents a general trend or merely an exception.

An interesting result was obtained with photocatalytic treatment of the phthalocyanine dye Reactive Green K5BL. Previous research to the treatment of a phthalocyanine dye (Turquoise Blue $G$ 133) by $\mathrm{TiO}_{2} / \mathrm{UV}$ suggested that the removal of this type of dyes is due to adsorption to the catalyst surface rather than to oxidative 
degradation (Arslan and Balcioğlu, 1999). In contrast to these findings, the results of the present study show a complete change of the shape of the UV-visible spectrum during photocatalytic treatment of Reactive Green K5BL (Fig. 3b). As adsorption of the dye would only lower the absorbance but not alter the shape of the spectrum, this result clearly points at oxidative transformation of the dye.

The residual UV-absorbance after photocatalytic treatment may be due to a recalcitrant organic fraction or to inorganic compounds. Especially nitrate and nitrite have a high absorption coefficient in the UV region: for instance nitrate's $\varepsilon(205 \mathrm{~nm})=8.75 \mathrm{mM}^{-1}$. Therefore, evaluation of the residual UV-absorbance can give an indication about the end products of photocatalytic oxidation of the $\mathrm{N}$ in azo and amino groups. The two long-term assays (29.3 and $30.4 \mathrm{~h}$ for Acid Orange 10 and its autoxidized reduced analogue, respectively) yielded a residual absorbance at $\lambda=205 \mathrm{~nm}$ of 2.54 and $3.70 \mathrm{mM}^{-1} \mathrm{~N}$, respectively, which corresponds to $29 \%$ and $42 \%$ of the absorbance that can be expected in case of complete oxidation of compounds' $\mathrm{N}$ to nitrate. In shorter assays with other dyes of known structure (for end times see Table 3 ), these percentages were 39\% (Acid Orange 12), 69\% (autoxidized reduced Acid Orange 12), 51\% (Reactive Black 5) and 48\% (autoxidized reduced Reactive Black 5). As these percentages were substantially lower than $100 \%$, and as it was clear that the UV-absorbance mainly decreased with increasing reaction time (Fig. 2), it can be concluded that nitrate was not the main reaction product. These observations are in agreement with the results reported by Hidaka et al. (1995), who reported that the final ratio between ammonia (a compound without UV-absorbance) and nitrate after photocatalytic treatment of Acid Orange 10 was higher than five. It is probable that ammonium was the main end product of photocatalytic degradation of the dyes' azo and amino groups. However, formation of recalcitrant $\mathrm{N}$-containing organics cannot be excluded.

The aerobic biodegradability of Acid Orange 10 was assessed by BOD determination. The BOD/COD ratio of Acid Orange 10 increased from 0 to 0.14 after chemical reduction followed by autoxidation. No BOD was detected after photocatalysis of the original dye or the autoxidized reduced dye. The relatively easy aerobically biodegradable substances produced by reduction and autoxidation are probably also easily degraded by photocatalysis. The pathway for anaerobic degradation and photocatalytic degradation of aromatic substances such as the dyes used in the present work are different: aromatic amines have been reported as intermediates in the case of natural anaerobic reduction while phenolic compounds have been detected in photocatalytic treatment (Tanaka et al., 2000).

In order to check whether the by-products of a photocatalytic treatment could be toxic to an anaerobic digestion consortium, anaerobic biodegradation tests were performed with four reactive dyes after photocatalysis. The methane production was not suppressed in the dye-containing bottles as it deviated less than 5\% from the blank. No real improvement of the color removal was observed (less than $5 \%$ ) but the decolorization yield of the photocatalytic process was already very large. This result is encouraging as some anthraquinone dyes have been found toxic to methanogens under mesophilic and thermophilic conditions (Dos Santos et al., 2005; Lee et al., 2006).

\section{Conclusions}

Photocatalysis leads to a high extent of color removal of both crude dye solutions and (autoxidized) reduced dye solutions. Its ability to decolorize dyes of distinct chemical classes (i.e. azo, anthraquinone, phthalocyanine dyes, representing the three most abundant types of textile dyes), including structures that have been shown toxic towards microbial activity, indicates that photocatalysis may be a feasible pre-treatment method for decolorization and detoxification of dye-containing wastewater.

The ability of photocatalysis to decolorize autoxidized solutions of chemically reduced azo dyes, as well as chemically reduced anthraquinone dyes, indicates its feasibility as a post-treatment method for decolorization of biorecalcitrant dyes (e.g. phthalocyanine and anthraquinone dyes) and dye residues (e.g. autoxidized aromatic amines from azo dyes) after biological treatment.

In addition to removing color, photocatalytic treatment also decreases, albeit at lower rates and to a lower extent, UV-absorbance and COD. Evaluation of the UV and COD data shows that, generally, more than $50 \%$ mineralization can be achieved during two h of treatment. However, since prolonged treatment $(\sim 30 \mathrm{~h})$ does not result in complete removal of UV and COD, it is obvious that complete mineralization does not occur.

Further experiments will be needed to monitor the end products and to assess the effect of other known constituents of textile wastewater (surfactants, salts, starch, etc).

\section{Acknowledgements}

The authors wish to thank J. Dussaud from Alstrohm. This work was partially supported by VOLUBILIS (Project MA/02/49) and PESSOA (Project 10807XH) programs. F.P. van der Zee received a grant from the Portuguese Fundação para Ciência e a Tecnologia (SFRH/ BPD/18748/2004).

\section{References}

Aleboyeh, A., Moussa, Y., Aleboyeh, H., 2005. Kinetics of oxidative decolourisation of Acid Orange 7 in water by ultraviolet radiation in the presence of hydrogen peroxide. Sep. Purif. Technol. 43, 143-148.

Alinsafi, A., Evenou, F., Abdulkarim, E.M., Pons, M.N., Zahraa, O., Benhammou, A., Yaacoubi, A., Nejmeddine, A., 2007. Treatment of textile industry wastewater by supported photocatalysis. Dyes Pigments 74, 439-445.

Arslan, I., Balcioğlu, I.A., 1999. Degradation of commercial reactive dyestuffs by heterogenous and homogenous advanced oxidation processes: a comparative study. Dyes Pigments 43, 95-108.

Bahnemann, D., 2004. Photocatalytic water treatment: solar energy applications. Sol. Energy 77, 445-459.

Baldrian, P., Merhautova, V., Gabriel, J., Nerud, F., Stopka, P., Hruby, M., Benes, M.J., 2006. Decolorization of synthetic dyes by hydrogen peroxide with heterogeneous catalysis by mixed iron oxides. Appl. Catal. B - Environ. 66, 258-264.

Bousselmi, L., Ghrabi, A., Ghozzi, K., Zayani, G., Ennabli, M., Geissen, S.U., Weidemeyer, A., Vogelpohl, A., Bahnemann, D., Hufschmidt, D., Pichat, P., 2002. Solar photocatalytic treatment of textile wastewater - possibilities and limitations in the Tunisian context. In: Proceedings of the International Symposium on Environmental Pollution Control Waste Management, pp. 804-812.

Chen, H.Y., Zahraa, O., Bouchy, M., Thomas, F., Bottero, J.Y., 1995. Adsorption properties of $\mathrm{TiO}_{2}$ related to the photocatalytic degradation of organic contaminants in water. J. Photochem. Photobiol. A 85, 179-186.

Delee, W., O'Neill, C., Hawkes, F.R., Pinheiro, H.M., 1998. Anaerobic treatment of textile effluents: a review. J. Chem. Technol. Biotechnol. 73, 323-335.

Dos Santos, A.B., Bisschops, I.A.E., Cervantes, F.J., Van Lier, J.B., 2005. The transformation and toxicity of anthraquinone dyes during thermophilic $\left(55^{\circ} \mathrm{C}\right)$ and mesophilic $\left(30^{\circ} \mathrm{C}\right)$ anaerobic treatments. J. Biotechnol. 115, 345353.

Drijvers, D., van Langenhove, H., Nguyen Thi Kim, L., Bray, L., 1999. Sonolysis of an aqueous mixture of trichloroethylene and chlorobenzene. Ultrason. Sonochem. $6,115-121$.

Easton, J.R., 1995. The dye maker's view. In: Cooper, P. (Ed.), Colour in Dyehouse Effluent. Society of Dyers and Colourists, Bradford, England, pp. 9-21.

Farré, M.J., Franch, M.I., Malato, S., Ayllon, J.A., Peral, J., Domenech, X., 2005. Degradation of some biorecalcitrant pesticides by homogeneous and heterogeneous photocatalytic ozonation. Chemosphere 58, 1127-1133.

Field, J.A., Stams, A.J.M., Kato, M., Schraa, G., 1995. Enhanced biodegradation of aromatic pollutants in cocultures of anaerobic and aerobic bacterial consortia. Anton. Leeuw. Int. J. G. 67, 47-77.

Getoff, N., 1996. Radiation-induced degradation of water pollutants - state of the art. Radiat. Phys. Chem. 47, 581-593.

Hidaka, H., Nohara, K., Zhao, J., Pelizzetti, E., Serpone, N., 1995. Photodegradation of surfactants XIV. Formation of $\mathrm{NH}_{4}^{+}$and $\mathrm{NO}_{3}^{-}$ions for the photocatalyzed mineralization of nitrogendashcontaining cationic, nondashionic and amphoteric surfactants. J. Photochem. Photobiol. A 91, 145-152. 
Kato, S., Hirano, Y., Iwata, M., Sano, T., Takeuchi, K., Matsuzawa, S., 2005. Photocatalytic degradation of gaseous sulfur compounds by silver-deposited titanium dioxide. Appl. Catal. B - Environ. 57, 109-115.

Kudlich, M., Hetheridge, M.J., Knackmuss, H.J., Stolz, A., 1999. Autoxidation reactions of different aromatic 0 -aminohydroxynaphthalenes that are formed during the anaerobic reduction of sulfonated azo dyes. Environ. Sci. Technol. 33, 896-901.

LaVerne, J.A., Enomoto, K., Araos, M.S., 2007. Radical yields in the radiolysis of cyclic compounds. Radiat. Phys. Chem. 76, 1272-1274.

Lee, Y.H., Matthews, R.D., Pavlostathis, S.G., 2006. Biological decolorization of reactive anthraquinone and phthalocyanine dyes under various oxidationreduction conditions. Water Environ. Res. 78, 156-169.

Legrini, O., Oliveros, E., Braun, A.M., 1993. Photochemical processes for water treatment. Chem. Rev. 93, 671-698.

Liu, H.N., Li, G.T., Qu, J.H., Li, H.J., 2007. Degradation of azo dye Acid Orange 7 in water by $\mathrm{Fe}-0 /$ granular activated carbon system in the presence of ultrasound. J. Hazard. Mater. 144, 180-186.

Malato, S., Blanco, J., Vidal, A., Richter, C., 2002. Photocatalysis with solar energy at a pilot-plant scale: an overview. Appl. Catal. B - Environ. 37, 1-15.

Minero, C., Pellizzari, P., Maurino, V., Pelizzetti, E., Vione, D., 2008. Enhancement of dye sonochemical degradation by some inorganic anions present in natural waters. Appl. Catal. B - Environ. 77, 308-316.

Neelavannan, M.G., Ahmed Basha, C., 2008. Electrochemical-assisted photocatalytic degradation of textile washwater. Sep. Purif. Technol. 61, 168-174.

Nigam, P., Banat, I.M., Singh, D., Marchant, R., 1996. Microbial process for the decolorization of textile effluent containing azo, diazo and reactive dyes. Process Biochem. 31, 435-442.
Ollis, D.F., 2000. Photocatalytic purification and remediation of contaminated air and water. C.R. Acad. Sci. II C, 405-411.

Pearce, C.I., Lloyd, J.R., Guthrie, J.T., 2003. The removal of colour from textile wastewater using whole bacterial cells: a review. Dyes Pigments 58, 179-196.

Pinheiro, H.M. Touraud, E. Thomas, O, 2004. Aromatic amines from azo dye reduction: status review with emphasis on direct UV spectrophotometric detection in textile industry wastewaters. Dyes Pigments 61, 121-139.

Prevot, A.B., Baiocchi, C., Brussino, M.C., Pramauro, E., Savarino, P., Augugliaro, V., Marci, G., Palmisano, L., 2001. Photocatalytic degradation of Acid Blue 80 in aqueous solutions containing $\mathrm{TiO}_{2}$ suspensions. Environ. Sci. Technol. 35, $971-$ 976.

Ruppert, G., Bauer, R., Heisler, G., 1993. The photo-Fenton reaction - an effective photochemical wastewater treatment process. J. Photochem. Photobiol. A 73, 75-78.

Stolz, A., 2001. Basic and applied aspects in the microbial degradation of azo dyes. Appl. Microbiol. Biotechnol. 56, 69-80.

Tanaka, K., Padermpole, K., Hisanaga, T., 2000. Photocatalytic degradation of commercial azo dyes. Water Res. 34, 327-333.

Theurich, J., Bahnemann, D.W., Vogel, R., Ehamed, F.E., Alhakimi, G., Rajab, I., 1997. Photocatalytic degradation of naphthalene and anthracene: GC-MS analysis of the degradation pathway. Res. Chem. Intermediat. 23, 247-274.

Van der Zee, F.P., Villaverde, S., 2005. Combined anaerobic-aerobic treatment of azo dyes - a short review of bioreactor studies. Water Res. 39, 1425-1440.

Zhang, Z., Yuan, Y., Liang, L., Fang, Y., Cheng, Y., Ding, H., Shi, G., Jin, L., 2008 Sonophotoelectrocatalytic degradation of azo dye on $\mathrm{TiO}_{2}$ nanotube electrode. Ultrason. Sonochem. 15, 370-375. 